UDC 004.07

\title{
Development of basic approaches to creating hardware and software for radiation monitoring information systems
}

\author{
M. Stervoyedov, V. Terokhin, O. Ridozub, S. Fomin
}

Stervoyedov Nikolay

Terokhin Vitaliy

Ridozub Oleh

Fomin Sergey
PhD (Technology), associate Professor; Head of the Department of electronics and control systems, V. N. Karazin Kharkiv national University, 6 Svobody square, Kharkiv-22, Ukraine, 61022

e-mail: styervoyedov@yahoo.com https://orcid.org/0000-0003-0136-6437

Aspirant of the Department of electronics and control systems, V. N. Karazin Kharkiv national University, 6 Svobody square, Kharkiv-22, Ukraine, 61022 e-mail:kbs-com@karazin.ua https://orcid.org/0000-0001-7653-4488

student of the faculty of Computer science, V. N. Karazin Kharkiv national University, 6 Svobody square, Kharkiv-22, Ukraine, 61022

e-mail: ridozub@gmail.com

https://orcid.org/0000-0003-0136-6437

PhD (Technology), of physical and mathematical Sciences, senior researcher of the Department of nuclear and medical physics of the faculty of physics and technology, V. N. Karazin Kharkiv national University, 6 Svobody square, Kharkiv-22, Ukraine, 61022

e-mail: fomin@nas.gov.ua https://orcid.org/0000-0002-4714-6141

Basic approaches to creating hardware and software for radiation monitoring information systems have been developed in the article. A modern information system for radiation monitoring and control that requires a comprehensive approach and an iterative process of its creation has been developed. The proposed approach to integrating local measuring devices with cloud services, using M2M/IoT technology for remote measurements, advanced semiconductor sensors based on CdTe and CdZnTe radiation detectors, modern microcontroller and communication microchips is highly promising. Developed hardware and software solutions demonstrate increased accuracy due to hardware and software correction of measurement results. A variant of the architectural solution for building a platform for remote access to dosimetric and radiometric measurements is being developed. The solution lies in the direction of improving the parameters of detectors, as well as the characteristics of electronic modules of detecting systems and creating software for controlling the detection process, collecting and digital processing of information, and its adequate presentation to users online. The architecture and structural diagram of a dosimetric system, a sequence diagram, a diagram of a dosimetric system with a subsystem for data exchange over the Internet have been created. A new algorithm for measuring the exposure dose rate of ionizing radiation has been proposed. The block diagram of a microcontroller dosimeter has been developed. The algorithm for correcting the dependence of the sensitivity of the detector based on CdZnTe on the energy of the detected gamma quanta has already been proposed. The algorithm significantly reduces the uncertainty of measuring the radiation dose rate. The architecture and block diagram of the dosimetric system with the possibility of remote access and remote control of the main functions has been presented as well. The calculation of the exposure dose of gamma radiation and the power of the exposure dose with the energy dependence correction have been used. The system elements have proved to be useful for students' distant laboratory work during the quarantine.

Keywords: radiation monitoring, microcontroller, dosimeter, detector, microcontroller, semiconductor sensors, charge-sensitive amplifier, cloud services, remote user access..

\section{Розробка основних підходів до створення апаратно-програмних засобів інформаційних систем радіаційного моніторингу}

Стервосдов

Микола

Григорович
М.Г.Стервоєдов, В.Л.Терьохін, О.В.Рідозуб, С.П.Фомін

к.т.н., доцент; завідуючий кафедри електроніки

та управляючих систем

Харківський національний університет імені В.Н.Каразіна,

Майдан Свободи 4,Харків-22, Украӥна, 61022 


\begin{tabular}{|c|c|}
\hline Терьохін & аспірант кафедри електроніки та управляючих систем \\
\hline Віталій & Харківський національний університет імені В.Н.Каразіна, \\
\hline Леонідович & Майдан Свободи 4,Харків-22, Украӥна, 61022 \\
\hline Рідозуб & студент факультету Комп'ютерних наук \\
\hline Олег & Харківський національний університет імені В.Н.Каразіна, \\
\hline Володимирович & Майдан Свободи 4,Харків-22, Україна, 61022 \\
\hline Фомін & к.ф.н, стариий науковий співробітник кафедри ядерної та \\
\hline Сергій & медичної фізики фізико-технічного факультету \\
\hline Петрович & $\begin{array}{l}\text { Харківський національний університет імені В.Н.Каразіна, } \\
\text { Майдан Свободи 4,Харків-22, Украйна, } 61022\end{array}$ \\
\hline
\end{tabular}

У цій статті розроблено базові підходи до створення апаратно-програмного забезпечення для інформаційних систем радіаційного контролю. Розроблено сучасна інформаційна система радіаційного контролю і моніторингу яка потребує комплексного підходу та ітеративного процесу її створення. При цьому, перспективним напрямком є запропонований підхід інтеграції локальних вимірювальних приладів з хмарними сервісами, застосування М2М/ІоТ технології для віддалених вимірювань, використання перспективних напівпровідникових сенсорів на основі CdTe и CdZnTe детекторів випромінювань, сучасної мікроконтролерної і комунікаційної мікросхемотехніки то що. Розроблені апаратні $\mathrm{i}$ програмні рішення мають підвищену точність за рахунок апаратно-програмної корекції результатів вимірювань. Розроблено варіант архітектурного рішення для побудови платформи для віддаленого доступу до дозиметричних та радіометричних вимірювань 3 пошуком шляхів вирішення цієї проблеми йде в напрямку поліпшення параметрів детекторів, удосконалення характеристик електронних модулів детектуючих систем і створення програмного забезпечення для управління процесом детектування, збором інформації, іiі цифрової обробки і адекватного представлення користувачам в on-line режимі. Створення архітектури та структурної схеми дозиметричної системи, діаграма послідовностей, схема дозиметричної системи 3 підсистемою обміну даними за допомогою Інтернет. Запропоновано новий алгоритм вимірювання потужності експозиційної дози іонізуючого випромінювання. Розробка структурної схеми мікроконтролерного дозиметра. Раніше був запропонований алгоритм корекції залежності чутливості детектора на основі CdZnTe від енергії реєстрованих гамма квантів. Алгоритм значно зменшує невизначеність вимірювання потужності дози опромінення. Також була розроблена архітектура і структурна схема дозиметричної системи $з$ можливістю віддаленого доступу та дистанційного управління основними функціями. Використано обчислення експозиційної дози гамма випромінювання і потужності експозиційної дози зі корекцією енергетичної залежності. Також, елементи системи виявилися корисними для дистанційного виконання лабораторних робіт студентами під час карантину.

Ключові слова: радіаційний моніторинг, мікроконтролерний дозиметр, детектор, мікроконтролер, напівпровідникові сенсори, зарядо - чутливий підсилювач, хмарні сервіси, віддалений доступ користувачів.

\section{Разработка основных подходов к созданию аппаратно-программных средств информационных систем радиационного мониторинга}

\section{Стервоедов \\ Николай \\ Григорьевич}

\author{
Терехин \\ Виталий \\ Леонидович \\ Ридозуб \\ Олег \\ Владимирович
}

Фомін

Сергій

Петрович

\section{Н.Г.Стервоедов, В.Л.Терехин, О.В.Ридозуб, С.П.Фомин}

к.т.н., доцент; заведующий кафедры електроники

и управляюших систем

Харковський национальный университет имени В.Н.Каразина, Площуадь Свободь 4,Харьков-22, Украина, 61022

аспирант кафедри електроники и управляющих систем Харковський наџиональный университет имени В.Н.Каразина, Площуадь Свободь 4,Харьков-22, Украина, 61022

студент факультета Компьютерных наук

Харковський национальный университет имени В.Н.Каразина, Площчадь Свободы 4,Харьков-22, Украина, 61022

к.ф.н, старший научный сотрудник кафедры ядерной и медицинской физики физико-технического факультету Харковський национальный университет имени В.Н.Каразина, Площуадь Свободы 4,Харьков-22, Украина, 61022 
В этой статье разработаны базовые подходы к созданию аппаратно-программного обеспечения для информационных систем радиационного контроля. Разработана современная информационная система радиационного контроля и мониторинга которая требует комплексного подхода и итеративного процесса ее создания. При этом, перспективным направлением является предложенный подход интеграции локальных измерительных приборов с облачными сервисами, применения М2M/IоT технологии для удаленных измерений, использования перспективных полупроводниковых сенсоров на основе CdTe и $\mathrm{CdZnTe}$ детекторов излучений, современной мікроконтролерної и коммуникационной микросхемотехники. Разработаны аппаратные и программные решения имеют повышенную точность за счет аппаратно-программной коррекции результатов измерений. Разработан вариант архитектурного решения для построения платформы для удаленного доступа к дозиметрическим измерениям с поиском путей решения этой проблемы идет в направлении улучшения параметров детекторов, усовершенствование характеристик электронных модулей детектирующих систем и создание программного обеспечения для управления процессом детектирования, сбором информации, ее цифровой обработки и адекватного представления пользователям в оn-line режиме. Создание архитектуры и структурной схемы дозиметрической системы, диаграмма последовательностей, схема дозиметрической системы с подсистемой обмена данными посредством Интернет. Предложен новый алгоритм измерения мощности экспозиционной дозы ионизирующего излучения. Разработка структурной схемы микроконтроллерного дозиметра. Ранее был предложен алгоритм коррекции зависимости чувствительности детектора на основе CdZnTe от энергии регистрируемых гамма квантов. Алгоритм значительно уменьшает неопределенность измерения мощности дозы облучения. Также была разработана архитектура и структурная схема дозиметрической системы с возможностью удаленного доступа и дистанционного управления основными функциями. Использовано вычисление экспозиционной дозы гамма излучения и мощности экспозиционной дозы с коррекцией энергетической зависимости. Также, элементы системы оказались полезными для дистанционного выполнения лабораторных.

Ключевые слова: радиационный мониторинг, микроконтроллерний дозиметр, детектор, микроконтроллер, полупроводниковые сенсоры, зарядо - чувствительный усилитель, облачные сервисы, удаленный доступ пользователей.

\section{Introduction}

The amount of ionizing radiation energy absorbed by a human body determines the degree of radiation damage to the functional organs [1]. Therefore, the correct measurement of the radiation dosage and new ways to increase the accuracy or reduce the uncertainty of the measured and calculated dosimetric values present an immediate problem. The search for solutions to this problem is based on improving the parameters of detectors, enhancing the characteristics of electronic modules of detecting systems, as well as creating software for controlling the detection process, collecting and processing information, and adequately representing it to users online [2,3]. When developing software, it is necessary to consider the interaction of ionizing radiation with materials and objects that are irradiated. In particular, it is necessary to consider their heterogeneity and the energy dependence of the detector sensitivity - the so-called "course with rigidity" - in a wide range of energy and radiation intensity, which is a nontrivial task [4].

Rapid development of information technologies and modern electronic database provide new opportunities for creating systems for monitoring the radiation state of objects and the impact of the radiation load on living organisms. Also, they are using M2M / IoT solutions for remote measurements, advanced semiconductor sensors (e.g. based on CdTe and CdZnTe radiation detectors), modern microcontroller technology, etc.

\section{General structure of hardware and software for radiation monitoring information systems}

The extremely useful hardware and software solution for online access to the information about the measuring dose and spectral composition of radiation, as well as parameters of detectors and spectrodosimetric equipment is the integration of local solutions with cloud technologies such as the ThingSpeak, a service for receiving, analyzing, and visualizing data. This service is free and has built-in MATLAB package - a high-level language and interactive environment for programming, numerical calculations and visualization of results. When using the package you can analyze data, develop algorithms, create models and applications [5].

The connection of equipment, a dosimeter in our case, is performed according to the Fig. 1. The ESP32 electronic module - a microcontroller with a Wi-Fi interface should be integrated in the device as suggested in [6].

The developed scheme is particularly useful for educational purposes. Using this solution, students will have remote access to research equipment via their smartphones and be able to use such powerful tools as MATLAB and SIMULINK for calculations. 


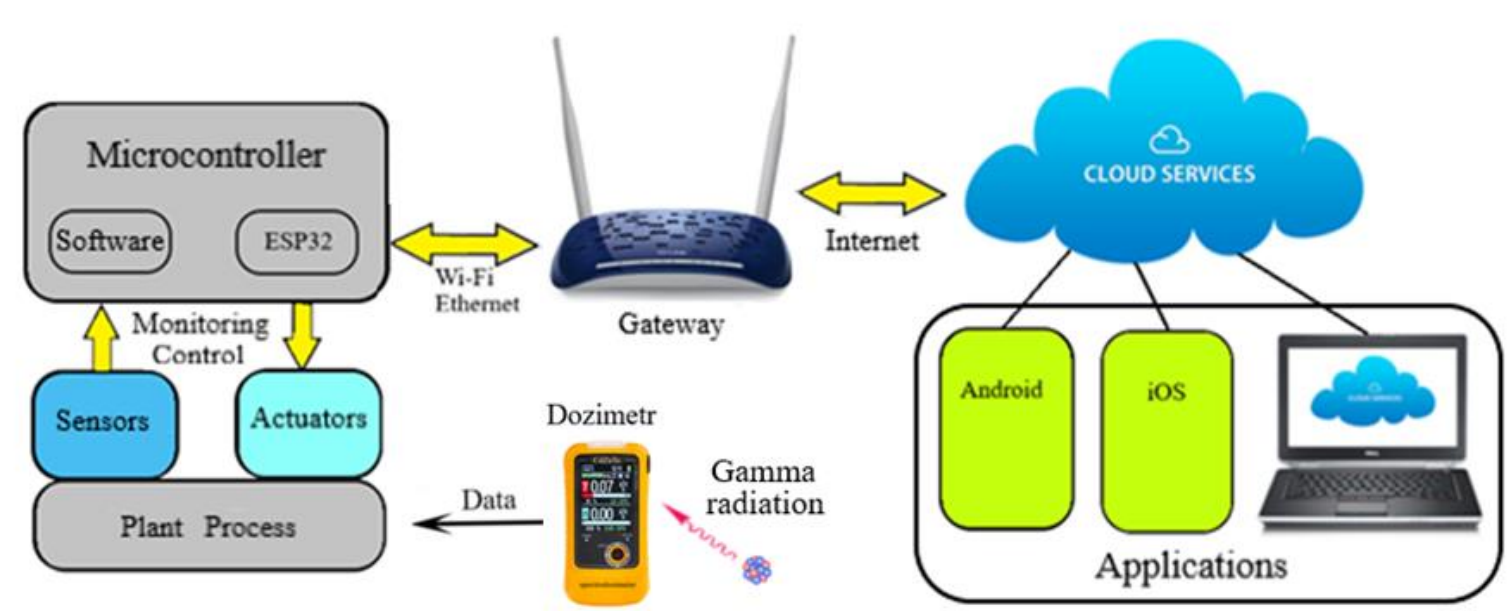

Fig. 1. The scheme of integrating the spectrodosimetric equipment with the cloud service.

The variation of the architectural solution for building a platform with remote access to dosimetric and radiometric measurements is presented in Fig. 2. The layout of the scheme for integrating dosimetric equipment with global networks is based on the STM32F4 Discovery microcontroller board and weither ESP8266 or ESP12 modules. Applying a single-board computer, for example, the Raspberry Pi and the ESP32-SX1278-Lora module is a cost-effective and robust option for creating a platform.

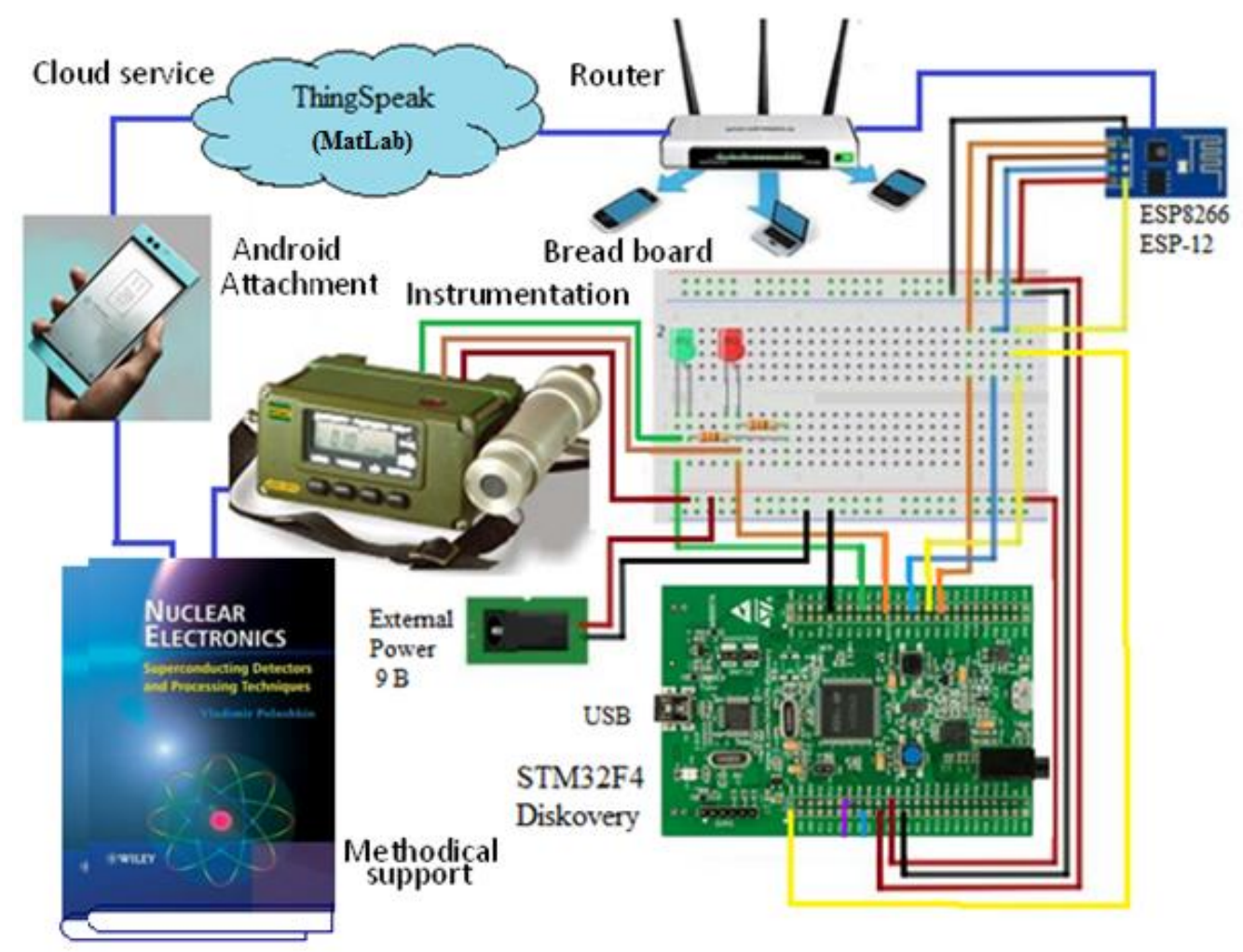

Fig. 2. The scheme for building a platform for remote user access to dosimetric and radiometric measurements.

The 137Cs (662 Kev) gamma-ray spectrum view on a smartphone screen obtained by using the Cd0.9Zn0.1Te detector is shown in Fig. 3 [7]. 


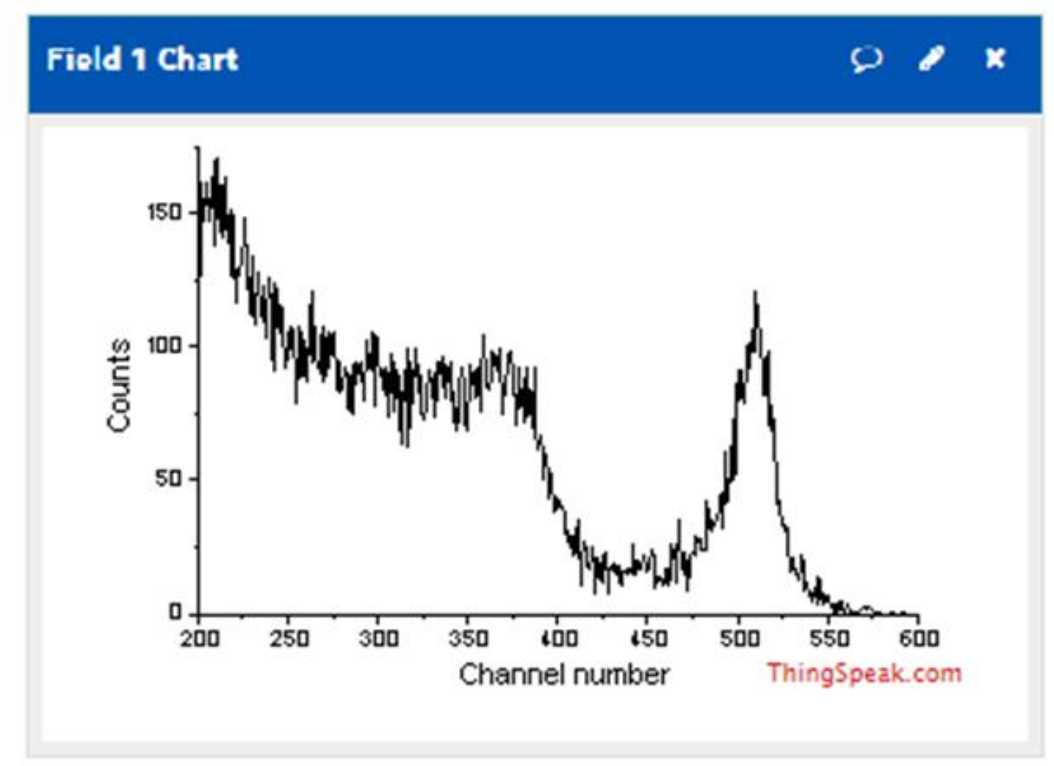

Fig. 3. Spectrum of 137Cs gamma quanta in a smartphone screen.

\section{Development of architecture and block diagram of the dosimetric system}

The graphical unified object modeling language UML-Unified Modeling Language is used for visual representation of the system functions. This modern tool is widely used in the development of software for modeling business processes, system design, and displaying organizational structures. The use case diagram developed by UML is presented in Fig. 4. This diagram visually represents various scenarios of interaction between actors (users) and precedents (use cases), and describes the functional aspects of the system (business logic).

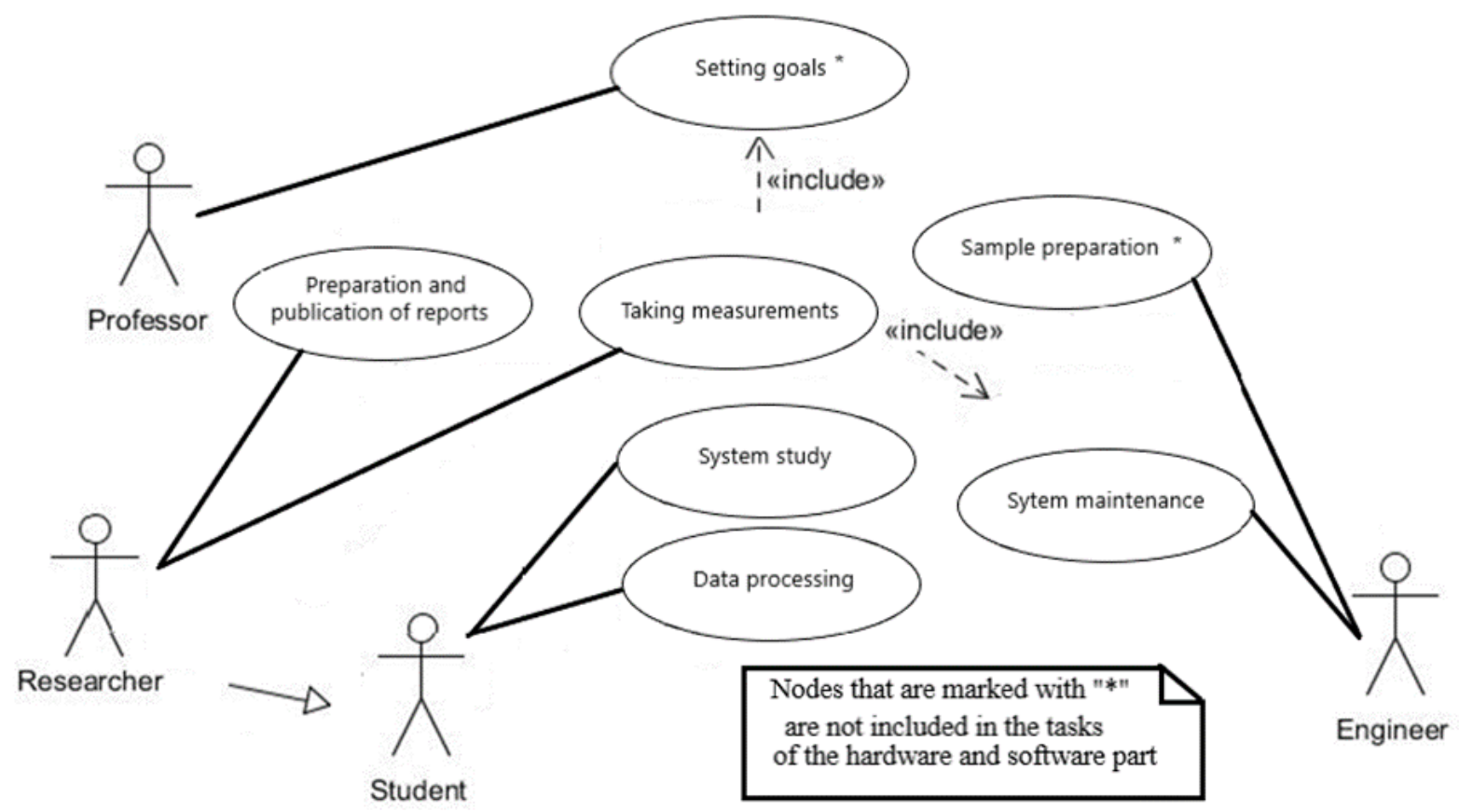

Fig. 4. UML use case diagram of the system functions.

According to the use case diagram, the system assumes that there are several classes of users who take part in the system operation.

There are two main types of users shown in the diagram: information consumers (students) and researchers who do not have direct access to the system hardware, and staff who have the necessary knowledge and authority to use complex devices of the dosimetry system to conduct experiments. 
It is planned that the system will include a certain number of dosimetric laboratories and a number of users. The advantage of using a web service in this case is that the work of distributing information to any number of users is performed by the service's servers. The ThingSpeak cloud service also allows you to create a channel with multiple data fields that can be recorded from different data collectors.

The process of systems interaction over time is represented in the sequence diagram shown in Fig. 5.

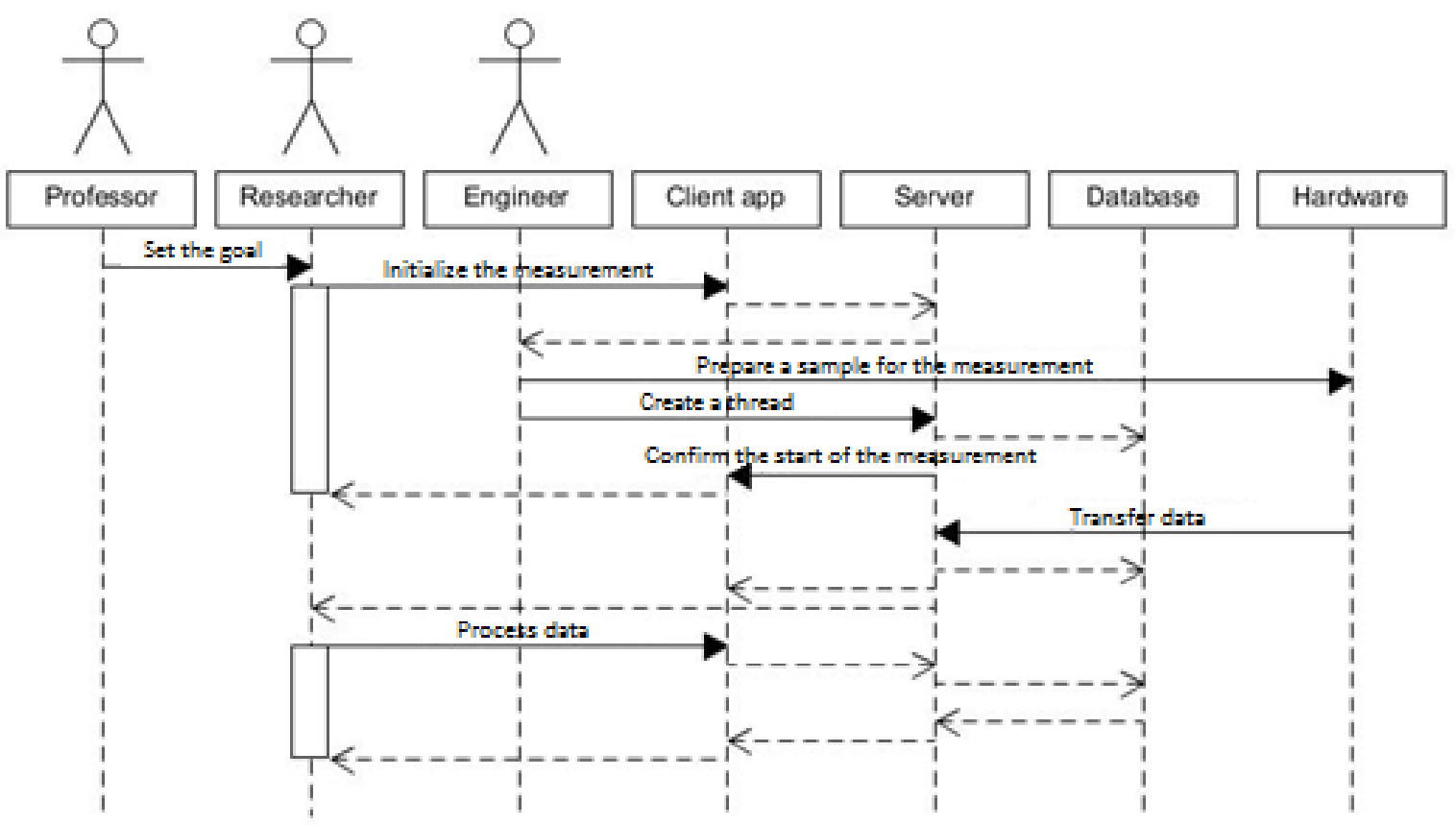

Fig. 5. UML sequence diagram of the system operation process.

Drawing up an idea of the necessary functions makes it possible to proceed to the system architecture development. As a result of collaboration with experts in the subject area, a block diagram of the dosimetric system has been developed (Fig. 6). The diagram includes both hardware and software subsystems.

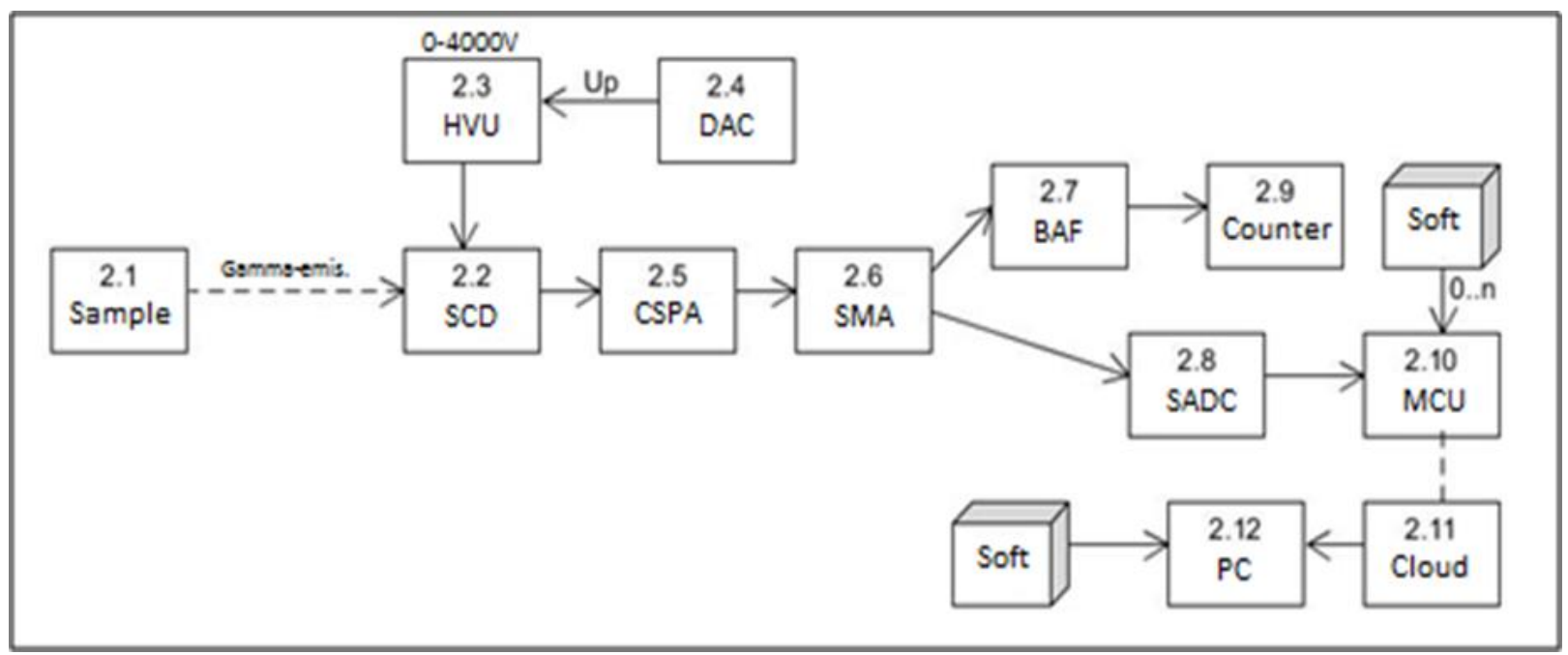

Fig. 6. The diagram of a dosimetric system with a subsystem for data exchange over the Internet.

The diagram shows the following components: 2.1-sample, 2.2-semiconductor detector, 2.3-highvoltage unit, 2.4-digital-to-analog converter, 2.5-charge-sensitive pre-amplifier, 2.6-spectrometric 
amplifier, 2.7-amplifier and shaper unit, 2.8-spectrometric ADC, 2.9-counter, 2.10-microcontroller, 2.11cloud service, 2.12-computer, software for dose determination and data processing.

\section{A block diagram of a microcontroller dosimeter development}

An algorithm for correcting the dependence of the sensitivity of the detector based on CdZnTe on the energy of the detected gamma quanta has been proposed previously [7]. The algorithm significantly reduces the uncertainty of measuring the radiation dose rate. The architecture and block diagram of the dosimetric system with the possibility of remote access and remote control of the main functions has been developed as well.

As can be seen from the proposed solutions, the necessary element of the system is an intelligent measuring dosimetric device that can be implemented on a modern microcontroller base.

The simplified block diagram of a microcontroller dosimeter is presented in Fig. 7. Electromagnetic radiation $(\gamma)$ is detected by the CdZnTe detector (D). A stable bias voltage is applied to the detector via a software-controlled power supply unit (CHVPS). Pulses from the detector are fed to a spectrometric module consisting of a charge-sensitive pre-amplifier (PA) and a main amplifier-shaper (FA). Basically, amplifiers are programmed to generate the optimal signal-to-noise ratio and the required gain.

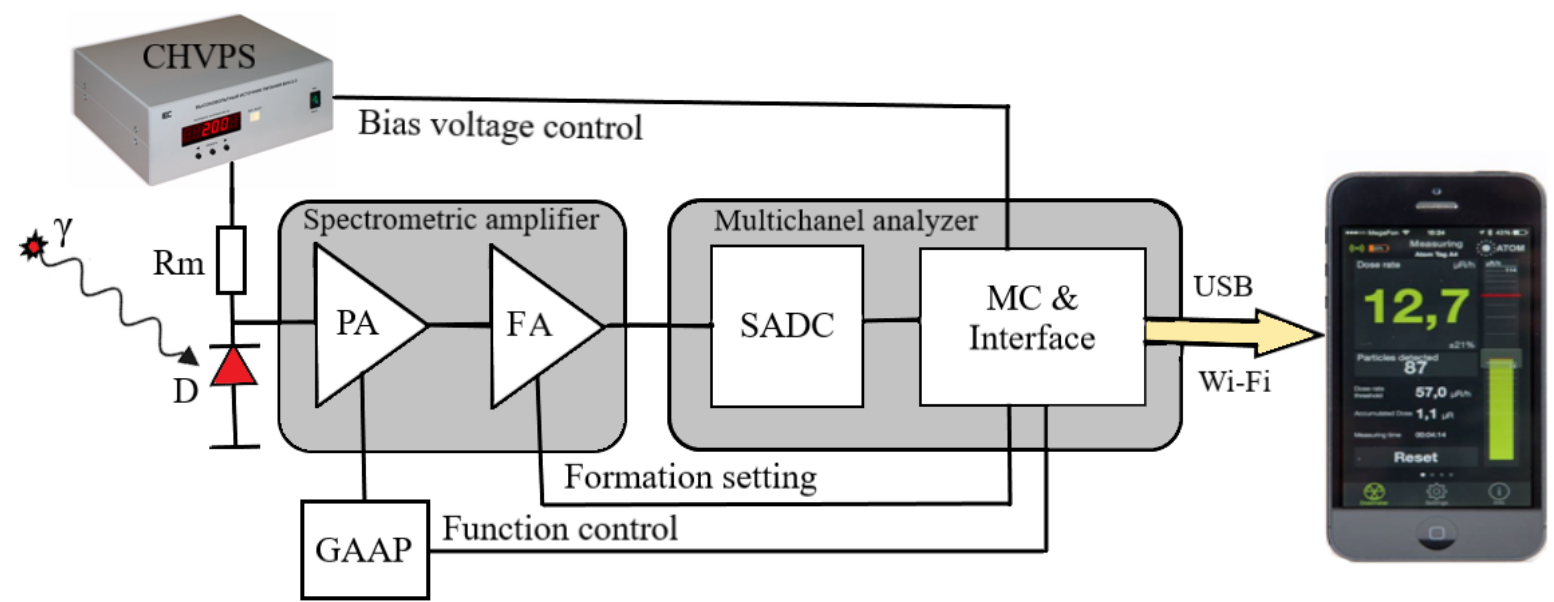

Fig. 7. The block diagram of the microcontroller dosimeter.

Voltage pulses whose amplitude is proportional to the energy of the detected gamma quanta are fed to the Board of a multi-channel amplitude analyzer. The analyzer consists of a spectrometric analog-todigital Converter (SADC) and a microcontroller module (MS \& Interface). In addition to counting the pulses from the registered gamma quanta, as it is done in a conventional dosimeter, the module generates exposure sets the necessary statistical accuracy of measurements, calculates correction coefficients and displays the measurement results. The module also provides the communication with a computer and the Internet services.

The module is proposed to be developed on the basis of a 32 - or 64-bit microcontroller. For example, it can be a STM32F407g-DISC1 debugging Board with a 32-bit ARM Cortex ${ }^{\circledR}$ - M4F microcontroller STM32F407VGT6 or a powerful Raspberry Pi 3 microcomputer on a $1.2 \mathrm{GHz}$ 64-bit Quad-core ARM Cortex-A53 CPU.

To find the optimal modes of the semiconductor detector, a programmable power supply unit controlled by a computer or microprocessor has been developed (Fig. 8). 


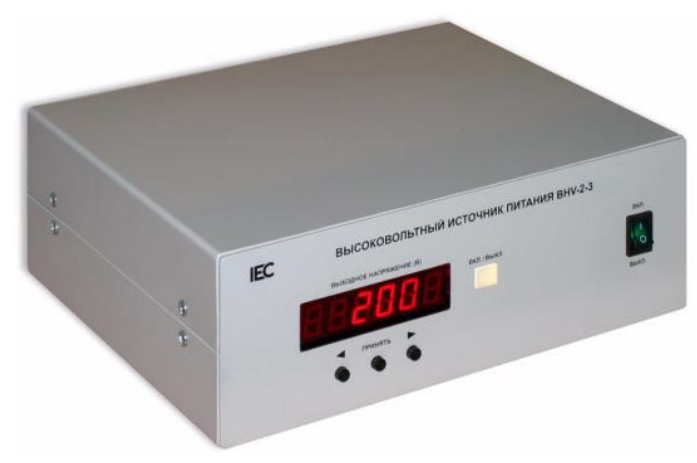

Fig. 8. Programmable high voltage power supply.

The device can be used to power photomultipliers, semiconductor ionizing radiation detectors and other low-power equipment, which requires high stability of the supplied voltage.

An example of using a programmable power supply to measure the dependence of the leakage current of a semiconductor ionizing radiation detector on the offset voltage is shown in Fig. 9.

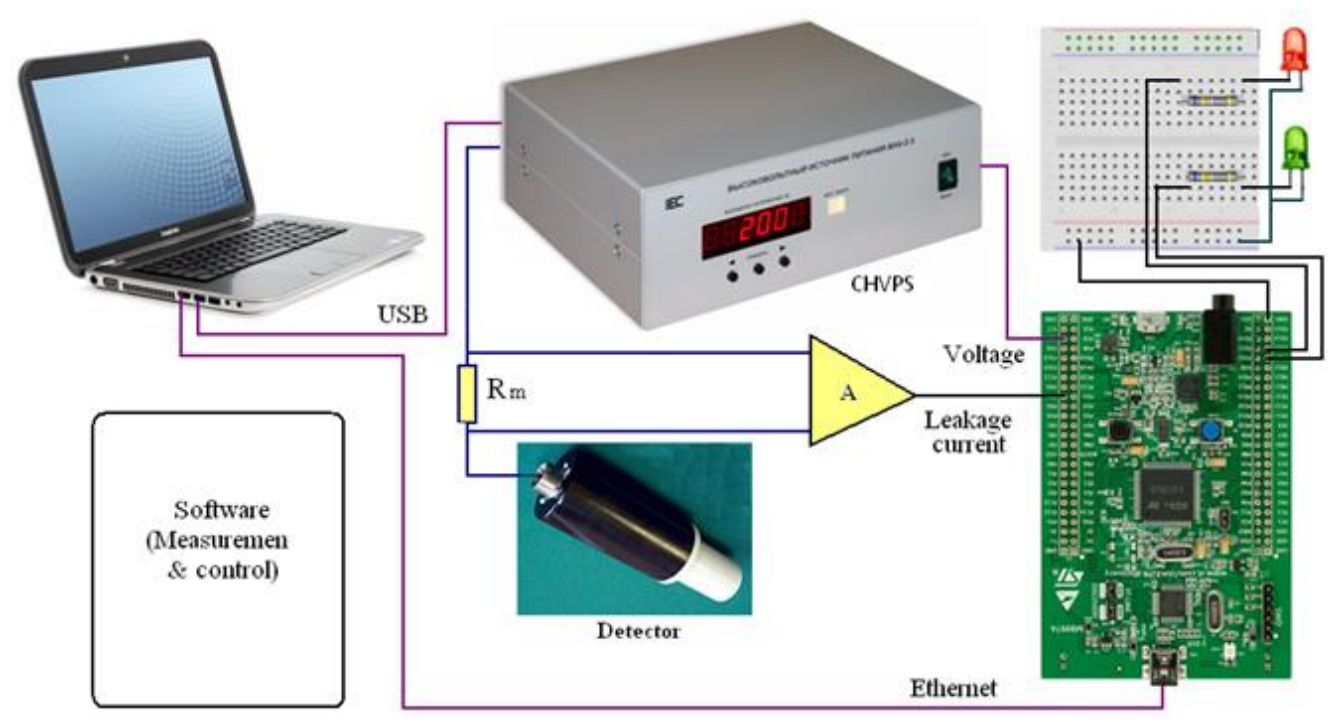

Fig. 9. The diagram of measuring the dependence of the leakage current on the offset voltage of the detector. $R$ measuring resistor, A-instrument amplifier with galvanic isolation.

The calculations of the exposure dose of gamma radiation and the exposure dose rate with the energy dependence correction.

Previously it has been suggested that the radiation dose measurement program operates in two modes : the preset exposure time mode or the set statistical uncertainty mode [6]. In the first mode, the spectrum set continues for the exposure time t. After the end of time t, the number of i pulses is recorded in each i - memory cell that is allocated for the multichannel amplitude analyzer, $N_{i}$ which shows how many pulses of this amplitude are received by the ADC input. Accordingly, the number of registered quanta of this energy is the same. The total number of $N_{\text {total }}$ pulses is calculated or calculated in parallel. In the second mode, $N_{\text {total }}$ is a value that is calculated based on the time when the maximum number of no pulses is reached $N_{0}$.

The calculations of the exposure dose of gamma radiation $D_{e}$ and the power of the exposure dose $X_{e}=D_{e} / t$ (4) are performed accounting for the recorded dependence of the CdZnTe detector sensitivity on the radiation energy [8]. To do this, after the spectrum is set, the program calculates $D_{e}$ in $[\mu \mathrm{r}]$, using the formulas (1):

$$
D_{e}=\left(\mathrm{A}<E_{\text {pulse }}>+B\right) * N_{\text {total }},
$$


where the average pulse amplitude $\left\langle E_{\text {pulse }}\right\rangle$ is calculated by using the formula (2):

$$
<E_{\text {pulse }}>=\sum i\left(i * n_{i} / N_{\text {total }}\right)
$$

and $N_{\text {total }}=\sum_{i} n_{i}-$ the total sum of pulses in the spectrum, or the final (3):

$$
D_{e}=A \sum i i * n_{i}+B * \sum i n_{i}
$$

The values of coefficients A and B are determined during calibration of the detector system using standard gamma-ray isotope sources.

The exposure dose rate of gamma radiation $X_{-}$e in $[\mu \mathrm{r} / \mathrm{s}]$ is defined as:

$$
X_{e}=D_{e} / t
$$

where $\mathrm{t}$ is the measurement time in seconds [s].

The calculated exposure dose value is transmitted via one of the interfaces to the dosimetric data representation subsystem.

Fully operational system, in addition to the program for determining radiation parameters, includes necessary software modules for adaptive control of the detector bias voltage, selection of time constants for forming circuits, setting of gain coefficients, and service programs.

\section{Conclusions}

The development of modern information systems for radiation monitoring and control requires a comprehensive approach and an iterative process of their development. The proposed promising approach is integrating local measuring devices with cloud services, using M2M/IoT technology for remote measurements, advanced semiconductor sensors based on $\mathrm{CdTe}$ and $\mathrm{CdZnTe}$ radiation detectors, modern microcontroller and communication microchips, etc. The developed hardware and software solutions have demonstrated high accuracy due to hardware and software correction of measurement results which are provided by a multi-channel amplitude analyzer implemented into the dosimetric system. The amplitude distribution which corresponds to the energy spectrum of radiation obtained during the exposure allows us to accurately calculate the exposure dose and the power of the exposure dose of gamma radiation. The ThingSpeak cloud service is used for providing users' access to information about the measuring dose, spectral composition of radiation, parameters of detectors and spectrodosimetric equipment. The developed equipment, algorithms, and programs are used for experimental research of radiation and nuclear-physical processes. The system elements have proved to be useful for students' distant laboratory work during the quarantine.

The work has been carried out with partial financial support from the UNTC Foundation, project No. 9903.

\section{ЛIТЕРАТУРА}

1. Григор'єва Л.І. Іонізуюче випромінювання та його вплив на людину. / Л.І. Григорєва, Ю.А. Томілі, І.М. Рожков. - Миколаїв : МДГУ ім.. Петра Могили, 2008. - 208 с. https://kegt-rshu.in.ua/images/dustan/LLIT.pdf

2. Кіцно В.О. Основи радіобіології та радіоекології. Навчальний посібник / В.О. Кіцно, С.В. Поліщук, І.М. Гудков - К. : Хай-Тек Прес, 2007. - 320 с. http://nubip.edu.ua/en/node/1184/3

3. Захарченко А.А. Моделирование энергетической зависимости чувствительности CdTe (CdZnTe) детекторов гамма-излучения / А.А. Захарченко, Д.В. Наконечный, И.Н. Шляхов, А.В. Рыбка, В.Е. Кутний, М.А. Хажмурадов // Технология и конструирование в электронной аппаратуре. - 2007. - № 1. - С. 28-31. http://dspace.nbuv.gov.ua/bitstream/handle/123456789/52644/06-Zakharchenko.pdf?sequence=1

4. Лазарєв Ю. Ф. МАТLAВ і моделювання динамічних систем. Навчальний посібник. - Київ: НТУУ "КПІ", 2009.

https://kafpson.kpi.ua/Arhiv/Lazarev/mds matlab.pdf 
5. Ridozub, O., Terokhin, V., Stervoyedov, N., Fomin, S.. Сенсорний вузол для бездротової мережі радіаційного моніторингу. Вісник Харківського національного університету імені В.Н. Каразіна, серія «Математичне моделювання. Інформаційні технології. Автоматизовані системи управління», 2019, 44, 88-93с.

https://periodicals.karazin.ua/mia/index

6. Ажажа В.M. Приборы на основе CdTe и CdZnTe для технологического контроля и мониторинга радиационной обстановки на АЭС / В.М. Ажажа, В.Е. Кутний, А.В. Рыбка, Л.Н. Давыдов, И.Н. Шляхов, А.А. Захарченко, Д.В. Кутний, Д.В. Наконечный // Наука та інновації. - 2006. - Т. 2, № 6. - С. 31-38.

http://dspace.nbuv.gov.ua/handle/123456789/113940

7. Захарченко А.А. Моделирование дозиметрических свойств детекторов гамма излучения на основе высокоомных полупроводников. Диссертация на соискание канд. физ. - мат. наук.

Харьков,2009 С. $28-31$.

http://dspace.nbuv.gov.ua/bitstream/handle/123456789/52427/10-Zakharchenko.pdf?sequence=1

\section{REFERENCES}

1. Grigoreva L. Ionizing radiation and its effect on humans. / L. I. Grigoreva L. A. Toml, and M.Rozhkov.-Mikolaiv: MDGU im.Petra Mogili, 2008 208p. https://kegtrshu.in.ua/images/dustan/LLIT.pdf [in Russia]

2. Kitsno V. O. Fundamentals of radiobiology and radioecology. Textbook / V. O. Kitsno, S. V. Polishchuk, I. M. Gudkov-K.: hi-Tech Pres, 2007. - 320 p. http://nubip.edu.ua/en/node/1184/3 [in Russia]

3. Zakharchenko A. A. Modeling of the energy dependence of the sensitivity Of CdTe (CdZnTe) detectors of gamma radiation / A. A. Zakharchenko, D. V. Nakonechny, I. N. Shlyakhov, A.V. Rybka, V. E. kutniy, M. A. Khazhmuradov / / Technology and design in electronic equipment. 2007. - no. 1. - Pp. 28-31. http://dspace.nbuv.gov.ua/bitstream/handle/123456789/52644/06Zakharchenko.pdf?sequence $=1$ [in Russia]

4. Lazarev Y. MATLAB and dynamic system modeling. Textbook. Navalny Oleshko. - Kiev: NTU "KPI", 2009. https://kafpson.kpi.ua/Arhiv/Lazarev/mds_matlab.pdf [in Ukraine]

5. Ridozub, O., Terokhin, V., Stervoyedov, N., Fomin, S.. Sensor node for wireless radiation monitoring network. Bulletin of V. N. Karazin Kharkiv national University series " Mathematical modeling. Information technology. Automated control system ", 2019, 44, 88-93c. https://periodicals.karazin.ua/mia/index [in Ukraine]

6. Azhazha V. Devices based on CdTe and CdZnTe for technological control and monitoring of the radiation situation at nuclear power plants / V. M. Azhazha, V. E. kutniy, A.V. Rybka, L. N. Davydov, I. N. Shlyakhov, A. A. Zakharchenko, D. V. kutniy, D. V. Nakonechny / / Nauka ta innovatsii. - 2006. - Vol. 2, No. 6. - Pp. 31-38.

http://dspace.nbuv.gov.ua/handle/123456789/113940 [in Russia]

7. Zakharchenko A. Modeling of dosimetric properties of gamma radiation detectors based on highresistance semiconductors. Dissertation for the competition for the candidate of physical and mathematical Sciences. Kharkiv, 2009 P. 28-31.

http://dspace.nbuv.gov.ua/bitstream/handle/123456789/52427/10-Zakharchenko.pdf?sequence=1 [in Ukraine] 